Article

\title{
Coal Chemical-Looping with Oxygen Uncoupling (CLOU) Using a Cu-Based Oxygen Carrier Derived from Natural Minerals
}

\author{
Ping Wang ${ }^{1, *(\mathbb{D}}$, Bret Howard ${ }^{1}$, Nicholas Means ${ }^{1,2}$, Dushyant Shekhawat ${ }^{3}$ and David Berry ${ }^{3}$ \\ 1 Department of Energy (DOE), National Energy Technology Laboratory (NETL), 626 Cochrans Mill Road, \\ Pittsburgh, PA 15236, USA; bret.howard@netl.doe.gov (B.H.); nicholas.means@netl.doe.gov (N.M.) \\ 2 Leidos Research Support Team, 626 Cochrans Mill Road, P.O. Box 10940, Pittsburgh, PA 15236-0940, USA \\ 3 DOE, NETL, 3610 Collins Ferry Road, Morgantown, WV 26507, USA; \\ Dushyant.Shekhawat@netl.doe.gov (D.S.); David.Berry@netl.doe.gov (D.B.) \\ * Correspondence: ping.wang@netl.doe.gov; Tel.: +1-412-386-7539
}

Received: 18 December 2018; Accepted: 9 April 2019; Published: 17 April 2019

\begin{abstract}
Chemical-looping with oxygen uncoupling (CLOU) is considered a promising technology to burn solid fuels with improved $\mathrm{CO}_{2}$ capture and has the potential to improve fuel conversion and reaction rates. $\mathrm{Cu}$-based oxygen carriers $(\mathrm{Cu}-\mathrm{OC})$ are often used in solid fuel CLOU. This study focused on investigating $\mathrm{Cu}-\mathrm{OC}$ derived from a natural mineral for solid fuel CLOU because of their potentially lower cost compared to synthetic OCs. Reactivity and recyclability of a natural ore-derived Cu-OC on coal char (Powder River Basin sub-bituminous coal) were studied at $900{ }^{\circ} \mathrm{C}$ in $\mathrm{Ar}$ and air using TGA-QMS and fixed-bed reactor-QMS for five cycles. Cu-OC was prepared by simply heating chalcopyrite in air. Chalcopyrite is one of the principle copper sulfide ores and one of the primary ores for copper. The prepared $\mathrm{Cu}$-OC had primarily $\mathrm{CuO}$ and $\mathrm{CuFe}_{2} \mathrm{O}_{4}\left(\mathrm{CuOFe}_{2} \mathrm{O}_{3}\right)$ as active compounds based on XRD analysis and an oxygen capacity $3.3 \%$ from oxygen uncoupling. The carbon conversion efficiency $X c$ was 0.94 for reduction at a ratio of $\mathrm{Cu}-\mathrm{OC}$ to char $\phi=75$ and the product gas was primarily $\mathrm{CO}_{2}$ with trace $\mathrm{O}_{2}$. The reactivities and the rates were similar for five redox cycles. These results indicate that the natural ore-derived material with low cost has potential as a competitive oxygen carrier in solid fuel CLOU based on its reactivity in this study.
\end{abstract}

Keywords: chemical-looping with oxygen uncoupling (CLOU); coal; Cu-based oxygen carrier; reactivity; recyclability; natural minerals; chemical-looping combustion

\section{Introduction}

Chemical-looping with oxygen uncoupling (CLOU) is a promising solid fuel chemical-looping combustion (CLC) process for $\mathrm{CO}_{2}$ emission control [1,2]. CLOU uses a solid oxygen carrier (OC) that releases gaseous $\mathrm{O}_{2}$ to combust the solid fuels [3]. It results in a higher fuel conversion and reaction rate than in-situ gasification CLC (iG-CLC), which uses an OC (typically Fe-based OC) to convert syngas generated from fuel gasification [1,4]. Some metal oxides with oxygen uncoupling properties are $\mathrm{CuO} / \mathrm{Cu}_{2} \mathrm{O}, \mathrm{Mn}_{2} \mathrm{O}_{3} / \mathrm{Mn}_{3} \mathrm{O}_{4}$, and $\mathrm{Co}_{3} \mathrm{O}_{4} / \mathrm{CoO}$ [3]. Cu-based OCs are often used in solid fuel CLOU and have demonstrated complete fuel conversion with near $100 \% \mathrm{CO}_{2}$ capture $[5,6]$. Cu-based OCs are also the focus of this study. Synthetic $\mathrm{Cu}$-based oxygen carriers ( $60 \mathrm{wt} . \% \mathrm{CuO}$ on a $\mathrm{MgAl}_{2} \mathrm{O}_{4}$ support) have successfully been tested in a $1.5 \mathrm{KW}$ th continuously-operating CLOU reactor using bituminous coal [7] and pine wood [8]. Recently, efforts towards development of OCs for CLOU have focused on combined metal oxides consisting of $\mathrm{Cu}$-based and $\mathrm{Mn}$-based materials mixed with $\mathrm{Ca}, \mathrm{Mg}, \mathrm{Cu}$, $\mathrm{Fe}$, or $\mathrm{Si}$ [9-11]. For reactivity and kinetic studies of the Cu-based OCs in CLOU, Thermogravimetric analysis (TGA) is typically used along with fixed bed and fluidized bed reactors [12-15]. The majority 
of studies focus on the oxygen uncoupling and oxidation of the Cu-based OCs or reduction of the Cu-based OC with gas fuels.

To fully convert solid fuels in CLOU, OCs with high $\mathrm{O}_{2}$ uncoupling capacity and/or low cost are required to generate excess oxygen [2,5]. Moreover, low cost OCs for reaction with solid fuels are preferred due to losses of $\mathrm{OC}$ in the challenging ash separation process, especially for coals with high ash content. Natural minerals are attractive for solid fuel CLC because of their potentially lower cost compared to synthetic OCs $[4,16]$. Natural copper ores have been investigated for CLOU and have demonstrated gaseous oxygen-releasing properties [17-21]. Three natural copper ores with low (5.82 wt.\%) and high (63.52 and $87.28 \mathrm{wt} . \%$ ) CuO content (primary mineral phase of $\mathrm{CuO}$ ) were studied in cycle tests of oxygen uptake in air and release in $\mathrm{CO}_{2}$ in a fluidized-bed reactor. The low $\mathrm{Cu}$ content ore did not have agglomeration for 20 cycles at a high temperature $\left(980^{\circ} \mathrm{C}\right)$ but both of the high $\mathrm{Cu}$ content ores showed agglomeration [21]. A medium $\mathrm{Cu}$ content $\mathrm{OC}(\mathrm{CuO} 21 \mathrm{wt.} \%$ and $\left.\mathrm{CuFe}_{2} \mathrm{O}_{4} 70 \mathrm{wt} . \%\right)$, prepared from natural copper ore, was evaluated for oxygen release/uptake rates and cyclic redox reactivity of anthracite coal CLOU at $900{ }^{\circ} \mathrm{C}$ and $950{ }^{\circ} \mathrm{C}$ in a batch fluidized-bed reactor [19]. The CLOU tests reached high combustion efficiency, above $96 \%$ and $\mathrm{CO}_{2}$ yields above 0.95. Slight agglomeration and sintering were observed during the $10 \mathrm{~h}$ of testing. The same copper ore OC was modified by mechanical mixing with cement (calcium aluminate cement 10-30 wt.\%) [20]. The modified OC with $20 \mathrm{wt} . \%$ cement was tested with both synthesis gas and lignite coal at $950{ }^{\circ} \mathrm{C}$ and showed better reactivity and improved agglomeration resistance than the unmodified copper ore OC. The same medium Cu content OC was also evaluated for CLOU with different coals (anthracite, bituminous, and lignite) over a range of temperatures $850-950{ }^{\circ} \mathrm{C}$ [18]. Carbon conversion rates decreased with the coal rank. No serious agglomeration was observed except for the high volatile lignite at $950^{\circ} \mathrm{C}$ due to radical temperature increase. Until recently, there has been little research on copper ore for coal CLOU and limited types of ores have been studied. Further investigation of copper ore for coal CLOU is needed [16].

Copper ores are abundant and consist of two primary types: copper sulfides and copper oxides [22]. Chalcopyrite $\left(\mathrm{CuFeS}_{2}\right)$ is one of the principle copper sulfide ores and the most important ore for copper production [23]. Therefore, chalcopyrite was selected for this study. Since the chalcopyrite ore is a naturally occurring mineral and is mined at a large scale, it often contains a large portion of gangue mineral including quartz, clay, and other non-copper-bearing minerals. During copper production, a copper concentrate is first generated from the chalcopyrite ore and typically consists of $24-28 \%$ copper, 23-25\% iron, and 25-30\% sulphur [24]. These copper concentrates could be a resource for OCs because they naturally contain both copper and iron and are readily available in large quantities in the ore markets. However, it has proven difficult to obtain small samples from copper mining companies for use in lab studies because of safety and security concerns when shipping these materials. Therefore, the ore used in this study was a chalcopyrite mineral sample but not the copper concentrate from mining companies. Coal is an abundant and inexpensive energy resource. Coal power plants generate large-scale, stable electricity output as part of the regional and global energy mix. The objective of this study is to investigate the reactivity and recyclability of natural copper ore for coal CLOU. Information resulting from this research could help to further develop low cost oxygen carriers for solid fuel CLOU technology.

\section{Experimental}

\subsection{Coal Char Preparation and Characterization}

Coal char was prepared by pyrolyzing a Powder River Basin (PRB) sub-bituminous coal obtained from the U.S. Department of Energy's National Carbon Capture Center (NCCC). Ground coal, with a particle size of $106-180 \mu \mathrm{m}$, was pyrolyzed at $1000^{\circ} \mathrm{C}$ for one hour in a fixed bed reactor under flowing nitrogen. Table 1 lists the proximate and ultimate analysis results for the coal and the coal char on a dry basis. The moisture content of the coal and char were $1.20 \mathrm{wt} . \%$ and $12.29 \mathrm{wt} . \%$, respectively. 
The pyrolysis temperature was selected to be higher than the CLOU test temperature $\left(900{ }^{\circ} \mathrm{C}\right)$ for the purpose of removing all volatile content from the char sample.

Table 1. Proximate and ultimate analysis of the Powder River basin (PRB) sub-bituminous coal and char.

\begin{tabular}{ccccccccc}
\hline \multirow{2}{*}{ Sample } & \multicolumn{3}{c}{ Proximate Analysis (\% Dry Basis) } & \multicolumn{4}{c}{ Ultimate Analysis (\% Dry Basis) } \\
\cline { 2 - 9 } & Fixed Carbon & Volatile Matter & Ash & C & H & N & S & O (Diff.) \\
\hline PRB Coal & 47.66 & 45.08 & 7.26 & 65.44 & 4.39 & 0.72 & 0.48 & 21.71 \\
PRB Char & 85.60 & 1.98 & 12.42 & 85.60 & 0.23 & 1.12 & 0.53 & 0.10 \\
\hline
\end{tabular}

\section{2. $\mathrm{Cu}$-Based $\mathrm{OC}(\mathrm{Cu}-\mathrm{OC})$ Preparation and Characterization}

The $\mathrm{Cu}-\mathrm{OC}$ was prepared from a chalcopyrite sample mined in Mexico. The chalcopyrite was analyzed to determine its mineral composition using X-ray diffraction (XRD) (PANalytical X'Pert PRO). The fresh chalcopyrite sample consisted of chalcopyrite $\left(\mathrm{CuFeS}_{2}, 75 \mathrm{wt} . \%\right)$ with minor quartz $\left(\mathrm{SiO}_{2}\right.$, $20 \mathrm{wt} . \%)$, trace kaolinite (a clay mineral, $\left.\mathrm{Al}_{2} \mathrm{Si}_{2} \mathrm{O}_{3}(\mathrm{OH})_{4}, 3 \mathrm{wt} . \%\right)$, and trace siderite $\left(\mathrm{FeCO}_{3}, 2 \mathrm{wt} . \%\right)$. The chalcopyrite ore composition by weight percentage was estimated by the reference intensity ratio (RIR) method from the XRD data. Table 2 summarizes the XRD analysis results for the various OC samples generated in this study.

Table 2. XRD analysis of main phase compounds in chalcopyrite, fresh $\mathrm{Cu}$-based oxygen carriers (Cu-OC), uncoupled $\mathrm{Cu}-\mathrm{OC}$, reduced, and reoxidized $\mathrm{Cu}-\mathrm{OC}$ with char in $\mathrm{Ar}$ at $900{ }^{\circ} \mathrm{C}$.

\begin{tabular}{|c|c|c|c|c|c|}
\hline \multicolumn{2}{|c|}{ Chalcopyrite } & \multirow[t]{2}{*}{ Fresh Cu-OC } & \multirow[t]{2}{*}{ Uncoupled Cu-OC } & \multirow{2}{*}{$\begin{array}{c}\text { Reduced Cu-OC } \\
\text { with Char }\end{array}$} & \multirow{2}{*}{$\begin{array}{c}\text { Reoxidized } \\
\text { Cu-OC with Char }\end{array}$} \\
\hline Chemical & $w t \%$ & & & & \\
\hline \multirow[t]{5}{*}{$\mathrm{CuFeS}_{2}$} & \multirow[t]{5}{*}{75} & \multirow{4}{*}{$\begin{array}{c}\mathrm{CuO} \\
\mathrm{CuFe}_{2} \mathrm{O}_{4}\left(\mathrm{CuOFe} \mathrm{O}_{3}\right) \\
\text { (tetragonal) }\end{array}$} & $\mathrm{Cu}_{2} \mathrm{O}$ & $\mathrm{Cu}_{2} \mathrm{O}$ & $\mathrm{CuO}$ \\
\hline & & & & & $\mathrm{CuFe}_{2} \mathrm{O}_{4}$ (tetragonal) \\
\hline & & & $\mathrm{CuFe}_{2} \mathrm{O}_{4}$ (cubic) & $\mathrm{CuFe}_{2} \mathrm{O}_{4}$ (cubic) & $\mathrm{CuFe}_{2} \mathrm{O}_{4}$ (cubic) \\
\hline & & & $\mathrm{CuFeO}_{2}\left(\mathrm{Cu}_{2} \mathrm{OFe}_{2} \mathrm{O}_{3}\right)$ & $\mathrm{CuFeO}_{2}$ & \\
\hline & & $\mathrm{Fe}_{2} \mathrm{O}_{3}$ & $\mathrm{Fe}_{2} \mathrm{O}_{3}$ & $\mathrm{Fe}_{2} \mathrm{O}_{3}$ & $\mathrm{Fe}_{2} \mathrm{O}_{3}$ \\
\hline $\mathrm{SiO}_{2}$ & 20 & $\mathrm{SiO}_{2}$ & $\mathrm{SiO}_{2}$ & $\mathrm{SiO}_{2}$ & $\mathrm{SiO}_{2}$ \\
\hline $\mathrm{FeCO}_{3}$ & 2 & & & & \\
\hline kaolinite & 3 & & & & \\
\hline
\end{tabular}

To prepare the $\mathrm{Cu}-\mathrm{OC}$, the chalcopyrite was crushed, ground, and sieved to a particle size range of $106-180 \mu \mathrm{m}$. The particles were then heated at $900{ }^{\circ} \mathrm{C}$ for two hours in a fixed bed reactor under flowing air to convert the sulfide ore to the oxide form releasing $\mathrm{S}$ as sulfur dioxide $\left(\mathrm{SO}_{2}\right)$. The selected heating temperature of $900^{\circ} \mathrm{C}$ to prepare the $\mathrm{Cu}-\mathrm{OC}$ was based on an ore oxidation behavior test using a TGA (Linsens HS-TGA) and a quadrupole mass spectrometer (QMS) (Pfeiffer Ominstar GSD 301) (Figure 1).

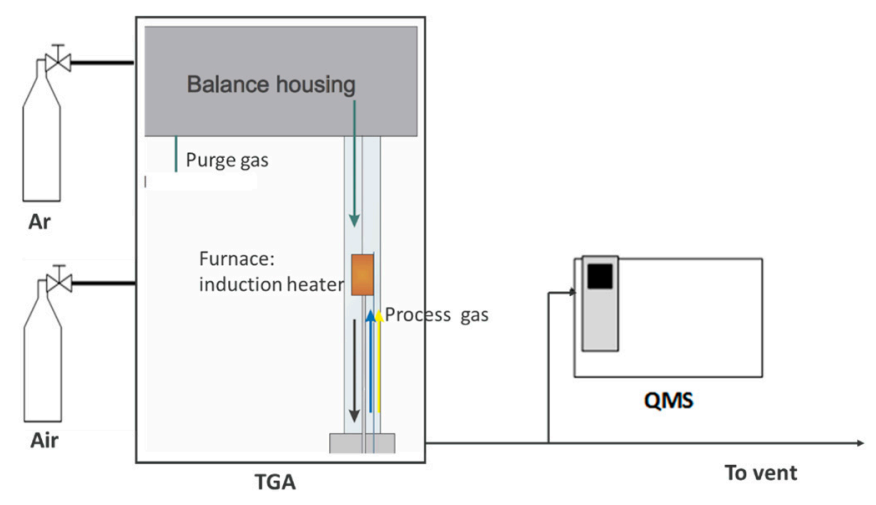

Figure 1. Schematic diagram of a thermogravimetric analyzer-quadrupole mass spectrometer (TGA-QMS) system used in this study. 
In the ore oxidation test, the ground chalcopyrite (approximately $175 \mathrm{mg}$ ) was tested under "simulated air" (22.4 vol.\% $\mathrm{O}_{2} / \mathrm{Ar}$ ) at $1000^{\circ} \mathrm{C}$ using a non-isothermal method. The sample was heated from room temperature to $100{ }^{\circ} \mathrm{C}$ at $5{ }^{\circ} \mathrm{C} / \mathrm{min}$ and held at $100^{\circ} \mathrm{C}$ for $1 \mathrm{~min}$ to remove moisture. Then, the temperature was increased to $1000{ }^{\circ} \mathrm{C}$ at $60^{\circ} \mathrm{C} / \mathrm{min}$ and held for about $30 \mathrm{~min}$. The product gases were analyzed on-line by the QMS every second during the reaction. The resulting $\mathrm{Cu}-\mathrm{OC}$ was analyzed to determine the crystalline phase composition by XRD.

During the TGA-QMS test of Cu-ore oxidation, the TGA detected the sample weight loss with a maximum rate at approximately $500{ }^{\circ} \mathrm{C}$. The final weight loss was approximately $16 \%$ and was primarily due to decomposition of $\mathrm{CuFeS}_{2}$ releasing $\mathrm{SO}_{2}$ with contributions from $\mathrm{FeCO}_{3}$ releasing $\mathrm{CO}_{2}$ and $\mathrm{Al}_{2} \mathrm{Si}_{2} \mathrm{O}_{3}(\mathrm{OH})_{4}$ releasing $\mathrm{H}_{2} \mathrm{O}$. All of the expected gases $\left(\mathrm{SO}_{2}, \mathrm{CO}_{2}\right.$ and $\left.\mathrm{H}_{2} \mathrm{O}\right)$ were detected by QMS during the chalcopyrite oxidation test. Figure 2 shows the $\mathrm{SO}_{2}$ ion current from the QMS and the sample temperature versus time for the ground chalcopyrite oxidation. Most of $\mathrm{SO}_{2}$ was released in the temperature range of $436-845^{\circ} \mathrm{C}$ with the maximum at about $600{ }^{\circ} \mathrm{C}$. Thus, the temperature of $900{ }^{\circ} \mathrm{C}$ was selected to prepare $\mathrm{Cu}-\mathrm{OC}$ from the chalcopyrite based on this result.

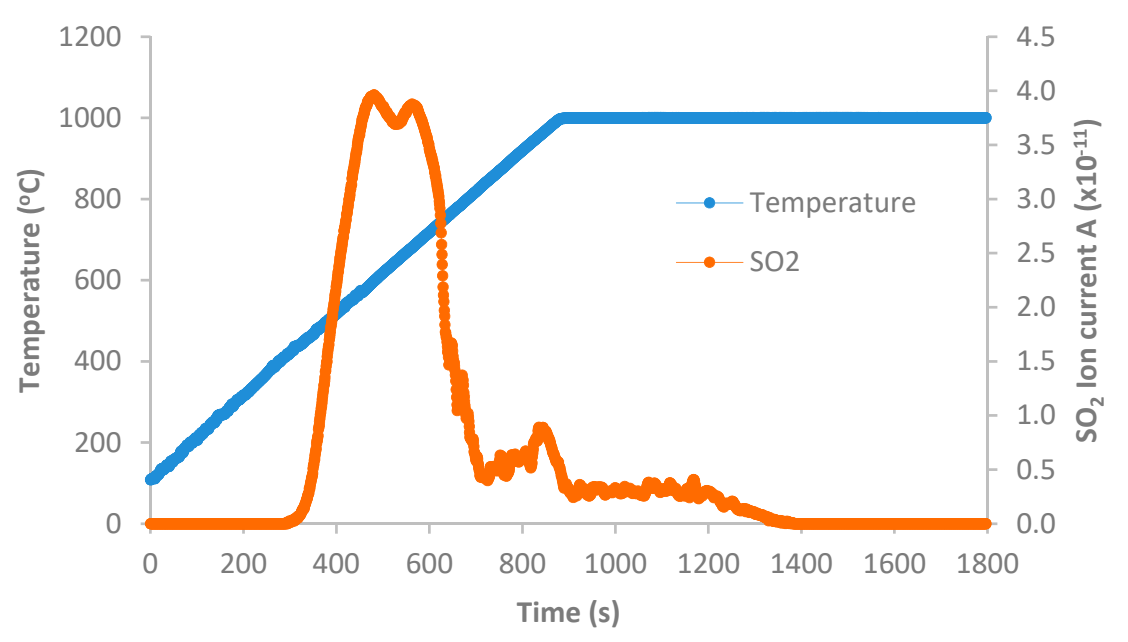

Figure 2. $\mathrm{SO}_{2}$ ion current from $\mathrm{QMS}$ and temperature versus time for the ground chalcopyrite oxidation in simulate air $\left(22.4\right.$ vol. $\left.\% \mathrm{O}_{2} / \mathrm{Ar}\right)$ at $1000{ }^{\circ} \mathrm{C}$ in a TGA-QMS.

The fresh Cu-OC consisted primarily of $\mathrm{CuO}$ (major component) and $\mathrm{CuFe}_{2} \mathrm{O}_{4}\left(\mathrm{CuOFe}_{2} \mathrm{O}_{3}\right.$, intermediate component) with minor amounts of hematite $\left(\mathrm{Fe}_{2} \mathrm{O}_{3}\right)$ and $\mathrm{SiO}_{2}$ from the XRD analysis (Table 2). The oxidation is a complex process and may involve several stages of reaction [23]. The overall oxidation of chalcopyrite may be viewed as follows:

$$
2 \mathrm{CuFeS}_{2}(\mathrm{~s})+(13 / 2) \mathrm{O}_{2}(\mathrm{~g}) \rightarrow 2 \mathrm{CuO}(\mathrm{s})+\mathrm{Fe}_{2} \mathrm{O}_{3}(\mathrm{~s})+4 \mathrm{SO}_{2}(\mathrm{~g})
$$

In the oxidation process, $\mathrm{CuFe}_{2} \mathrm{O}_{4}$ may be formed from $\mathrm{CuO}$ and $\mathrm{Fe}_{2} \mathrm{O}_{3}$. Conversion of the chalcopyrite to an oxygen carrier is a relatively simple process compared to synthetic $\mathrm{Cu}$-Fe OC preparation which could require multiple steps and many chemicals, another benefit of using chalcopyrite as a resource for a $\mathrm{Cu}$-based $\mathrm{OC}$ with low cost.

\subsection{Analysis of the $\mathrm{Cu}-\mathrm{OC}$}

\subsubsection{Cu-OC Oxygen Uncoupling}

$\mathrm{Cu}-\mathrm{OC}$ oxygen uncoupling was tested using a TGA-QMS under $\mathrm{Ar}$ at $60 \mathrm{~mL} / \mathrm{min}$. A sample of the $\mathrm{Cu}-\mathrm{OC}$ (approximately $30 \mathrm{mg}$ ) was heated from room temperature to $100{ }^{\circ} \mathrm{C}$ at $30{ }^{\circ} \mathrm{C} / \mathrm{min}$ and held at $100^{\circ} \mathrm{C}$ for $5 \mathrm{~min}$ to remove moisture from the OC. Then the temperature was increased to $900{ }^{\circ} \mathrm{C}$ at $60^{\circ} \mathrm{C} / \mathrm{min}$ and held for about $60 \mathrm{~min}$. The QMS quantified the oxygen gas $\left(\mathrm{O}_{2}\right)$ on-line every second 
during the reaction. The resulting reduced $\mathrm{Cu}-\mathrm{OC}$ was analyzed to determine the crystalline phase composition by XRD.

The non-isothermal method used in this study was done to quantify the gaseous oxygen released from the OC. For the isothermal method used for CLOU, a sample was heated to the test temperature in an air atmosphere then tested by switching to inert gas [25]. In the isothermal method, it is difficult to determine the released oxygen from the OC because the gas from the TGA is a mixture of residual oxygen from the air and the released $\mathrm{O}_{2}$ from the $\mathrm{OC}$ with a relatively low concentration $\left(<1 \% \mathrm{O}_{2}\right.$ in this study).

\subsubsection{Recyclability of the Cu-OC with Coal Char in a TGA-QMS}

The recyclability of the $\mathrm{Cu}-\mathrm{OC}$ with coal char CLOU was evaluated at $900{ }^{\circ} \mathrm{C}$ for five cycles in the TGA-QMS. For one CLOU cycle, $\mathrm{Cu}-\mathrm{OC}$ reduction with the coal char was first tested under Ar using the same experimental procedure described in Section 2.3.1. A test sample of the $\mathrm{Cu}-\mathrm{OC}$ and the char was physically mixed with a ratio of $\mathrm{Cu}-\mathrm{OC}$ to char $(\phi)$ by weight of 75 . This ratio was calculated based on oxygen. The available gaseous oxygen in the $\mathrm{Cu}-\mathrm{OC}$ from oxygen uncoupling is the stoichiometric amount of oxygen required to fully combust the char to $\mathrm{CO}_{2}$ (Reaction $\mathrm{R} 2$ ). After the reduction of the sample, the reduced $\mathrm{Cu}-\mathrm{OC}$ was immediately reoxidized at $900{ }^{\circ} \mathrm{C}$ for about 15 min under an oxygen gas environment. The oxygen gas was 22.4 vol. $\% \mathrm{O}_{2} / \mathrm{Ar}$ at $60 \mathrm{~mL} / \mathrm{min}$. The QMS quantified the primary reaction gases $\left(\mathrm{O}_{2}, \mathrm{CO}, \mathrm{CO}_{2}, \mathrm{CH}_{4}\right.$, and $\left.\mathrm{H}_{2}\right)$. The reduced and reoxidized $\mathrm{Cu}-\mathrm{OC}$ were analyzed to determine the crystalline phase composition by XRD.

$$
\mathrm{C}(\mathrm{s})+\mathrm{O}_{2}(\mathrm{~g}) \rightarrow \mathrm{CO}_{2}(\mathrm{~g})
$$

After one CLOU cycle, the system was cooled to room temperature. The gas was switched to Ar for 2nd cycle testing. The same amount of coal char was again added to the sample crucible with the oxidized $\mathrm{Cu}-\mathrm{OC}$ and coal ash from the previous cycle. The 2 nd cycle and subsequent cycles were conducted following the same procedure.

\subsubsection{Recyclability of the Cu-OC with Coal Char in a Fixed Bed Reactor-QMS System}

The same multicycle tests were repeated using a fixed bed reactor-QMS system to generate samples for BET surface area analysis. The purpose of this test was to obtain more sample for the BET measurements because Cu-OCs, like other OCs, have low surface areas. The BET surface areas of the fresh and used $\mathrm{Cu}-\mathrm{OC}$ were evaluated by $\mathrm{N}_{2}$ adsorption isotherms performed at $77 \mathrm{~K}$ in a Quantachrome Autosorb 1-C.

\subsection{Data Analysis}

For TGA data, the reactivities of the $\mathrm{Cu}-\mathrm{OC}$ are evaluated based on mass changes in solids. The $\mathrm{Cu}-\mathrm{OC}$ oxygen uncoupling, reduction, and re-oxidation reactivity with coal char, and recyclability were evaluated by calculating sample weight change and rates of change. $m_{0}$ for oxygen uncoupling, $m_{\text {red }}$ for reduction, and $m_{o x}$ for oxidation are defined as follows:

$$
\begin{aligned}
m_{o} & =\frac{m_{o c}-m}{m_{o c}} \times 100 \\
m_{r e d} \text { or } m_{o x} & =\frac{m-\left(m_{o c}+m_{c}\right)}{m_{o c}+m_{c}} \times 100
\end{aligned}
$$

where $m, m_{o c}$ and $m_{c}$ are the mass of the test sample at the reaction time, the initial mass of the Cu-OC and the initial mass of the coal char, respectively. The maximum oxygen uncoupling $m_{o}$ is the oxygen transport capacity $\mathrm{R}_{\mathrm{oc}}\left(\mathrm{R}_{\mathrm{oc}}=\left(m_{o x}-m_{r e d}\right) / m_{o x}{ }^{*} 100, m_{o x}\right.$ : mass of the fully oxidized oxygen carrier; $m_{r e d}$ : mass of the reduced oxygen carrier [4]). 
For QMS data, the reactivities of the $\mathrm{Cu}-\mathrm{OC}$ are evaluated based on changes in the number of moles of the gases produced. The oxygen uncoupling $\left(X_{O}\right)$ was determined by calculating the moles of oxygen generated by uncoupling and rate of the change is $(d X o / d t)$. Xo is defined as follow:

$$
\text { Xo }=\frac{n}{n_{\max }}
$$

where $n$ is the moles of oxygen generated over the reaction time $(t)$ and $n_{\max }$ is the maximum moles of the oxygen generated.

In the coal char CLOU, the char reacted with gaseous oxygen released by heating $\mathrm{Cu}-\mathrm{OC}$ and generated primarily $\mathrm{CO}_{2}$ and $\mathrm{CO}$. The reactivity of the coal char was evaluated by calculating the carbon conversion efficiency $(X c)$ and its rate $(d X c / d t)$ based on the QMS data [5]. Xc is defined as follows:

$$
X c=\frac{n_{c}}{n_{0}}=\frac{\sum_{t=0}^{t} F\left(y_{\mathrm{CO} 2}+y_{\mathrm{CO}}\right)}{n_{0}}
$$

where $n_{c}$ is the moles of carbon in product gases such as $\mathrm{CO}_{2}$ and $\mathrm{CO}$ over the reaction time $n_{0}$ is the moles of the carbon in the initial coal char sample; $F$ is the gas flow rate; and $y_{i}$ is volumetric concentrations of the carbon containing gas (i).

A major purpose for developing coal CLOU is for $\mathrm{CO}_{2}$ emission control, so a primary goal of coal CLOU is to convert carbon to $\mathrm{CO}_{2}$. In this study, the coal CLOU process performance was evaluated by calculating the $\mathrm{CO}_{2}$ conversion efficiency $\left(\mathrm{Sco}_{2}\right)$ based on the QMS data [5]. $\mathrm{Sco}_{2}$ is defined as follows:

$$
\mathrm{ScO}_{2}=\frac{n_{\mathrm{CO} 2}}{n_{t}}
$$

where $n_{c 02}$ and $n_{t}$ are the total moles of accumulated carbon in $\mathrm{CO}_{2}$ and in the total carbon containing product gases over the reaction time $(t)$, respectively.

\section{Results and Discussion}

\subsection{Cu-OC Oxygen Uncoupling}

When the $\mathrm{Cu}-\mathrm{OC}$ was heated over $600{ }^{\circ} \mathrm{C}$, gaseous $\mathrm{O}_{2}$ was initially generated and detected by the QMS in the product gas and simultaneously a sample weight loss was detected by the TGA (Figures 3 and 4). When the temperature was increased over $820{ }^{\circ} \mathrm{C}$, the gaseous $\mathrm{O}_{2}$ concentration and the oxygen uncoupling rate quickly increased with a maximum at $900{ }^{\circ} \mathrm{C}$ (Figures 3 and 4). These oxygen uncoupling behaviors of the $\mathrm{Cu}-\mathrm{OC}$ were similar to those of pure $\mathrm{CuO}$ [5]. Based on the TGA data, the maximum oxygen uncoupling $\left(\mathrm{R}_{\mathrm{oc}}\right)$ and oxygen uncoupling rate were $3.3 \%$ and $0.0032 \% / \mathrm{s}$, respectively (Table 3). Table 3 summarizes the reactivities results of OC uncoupling and carbon conversion in reduction for the $\mathrm{Cu}-\mathrm{OC}$ in this study and pure $\mathrm{CuO}$ from reference [5]. The oxygen uncoupling $\left(\mathrm{R}_{\mathrm{oc}}\right)$ was similar to the $4 \%$ oxygen uncoupling of $40 \mathrm{wt} . \% \mathrm{CuO}$ with $\mathrm{ZrO}_{2}$ support OC synthesized by mechanical mixing followed by pelletizing by pressure [25].

\begin{tabular}{|c|c|c|c|c|c|c|c|c|c|}
\hline \multirow[b]{2}{*}{ Sample } & \multirow[b]{2}{*}{$\mathrm{T}\left({ }^{\circ} \mathrm{C}\right)$} & \multicolumn{3}{|c|}{ Oxygen Uncoupling } & \multicolumn{4}{|c|}{ Carbon Conversion in Reduction } & \multirow[b]{2}{*}{ Test System } \\
\hline & & $\begin{array}{c}m_{o \max } \\
\mathrm{R}_{\mathrm{oc}}(\%)\end{array}$ & $\begin{array}{c}\text { Tmax } \\
\left({ }^{\circ} \mathrm{C}\right)\end{array}$ & $\begin{array}{c}\mathrm{dXo} / \mathrm{dtmax} \\
(1 / \mathrm{s})\end{array}$ & $X_{c}$ & $\mathrm{Sco}_{2}$ & $\begin{array}{c}\text { Tmax } \\
\left({ }^{\circ} \mathrm{C}\right)\end{array}$ & $\begin{array}{c}\mathrm{dXc} / \mathrm{dtmax} \\
(1 / \mathrm{s})\end{array}$ & \\
\hline $\mathrm{Cu}$ ore $\mathrm{OC}$ & 900 & 3.3 & 900 & 0.0012 & & & & & TGA-QMS \\
\hline \multirow[t]{2}{*}{ Pure $\mathrm{CuO}$} & 850 & 10 & 850 & 0.0015 & & & & & fixed bed-QMS \\
\hline & 950 & 10 & 922 & 0.0077 & & & & & fixed bed-QMS \\
\hline $\mathrm{Cu}$ ore $\mathrm{OC} / \mathrm{char}$ & 900 & & & & 0.94 & 1 & 838 & 0.005 & TGA-QMS \\
\hline$\phi=75$ & 900 & & & & 0.95 & 1 & 835 & 0.006 & fixed bed-QMS \\
\hline Pure $\mathrm{CuO} / \mathrm{char}$ & 850 & & & & 0.98 & 1 & 801 & 0.006 & fixed bed-QMS \\
\hline$\phi=26$ & 950 & & & & 0.99 & 1 & 833 & 0.011 & fixed bed-QMS \\
\hline
\end{tabular}

Table 3. Oxygen capacity, carbon conversion efficiency, maximum conversion, and conversion rates and temperatures for $\mathrm{Cu}$ ore $\mathrm{OC}$ in $\mathrm{Ar}$ at $900{ }^{\circ} \mathrm{C}$ and pure $\mathrm{CuO}$ from reference [5]. 
The fresh $\mathrm{Cu}-\mathrm{OC}$ consisted primarily of major amounts of $\mathrm{CuO}$ and intermediate amounts of $\mathrm{CuFe}_{2} \mathrm{O}_{4}\left(\mathrm{CuOFe}_{2} \mathrm{O}_{3}\right)$. $\mathrm{CuO}$ released gaseous $\mathrm{O}_{2}$ and was reduced to $\mathrm{Cu}_{2} \mathrm{O}$ at temperatures above 600 ${ }^{\circ} \mathrm{C}$ (Reaction $\mathrm{R} 3$ [3]). XRD indicated that $\mathrm{Cu}_{2} \mathrm{O}$ was generated and no $\mathrm{CuO}$ was detected in the residue of the $\mathrm{Cu}-\mathrm{OC}$ oxygen uncoupling test. $\mathrm{CuFe}_{2} \mathrm{O}_{4}$ decomposes to generate gaseous $\mathrm{O}_{2}$, delafossite $\left(\mathrm{CuFeO}_{2}\right.$ ), and $\mathrm{Fe}_{2} \mathrm{O}_{3}$ (Reaction R4) [26]. The XRD analysis of this residue also showed that a Cu-Fe-O compound of $\mathrm{CuFeO}_{2}\left(\mathrm{Cu}_{2} \mathrm{OFe}_{2} \mathrm{O}_{3}\right)$ formed. The $\mathrm{Fe}_{2} \mathrm{O}_{3}$ decreased and the $\mathrm{CuFe}_{2} \mathrm{O}_{4}\left(\mathrm{CuOFe}_{2} \mathrm{O}_{3}\right)$ phase changed (tetragonal to cubic) compared to the fresh Cu-OC (Table 2). So, some $\mathrm{CuFe}_{2} \mathrm{O}_{4}$ in the $\mathrm{Cu}-\mathrm{OC}$ decomposed and released $\mathrm{O}_{2}$ because $\mathrm{CuFe}_{2} \mathrm{O}_{4}$ was detected by the XRD. Both $\mathrm{CuO}$ and $\mathrm{CuFe}_{2} \mathrm{O}_{4}$ are active compounds in the $\mathrm{Cu}-\mathrm{OC}$. Zhao et al. studied a $\mathrm{Cu}$-ore oxygen carrier with $21 \% \mathrm{CuO}$ and reported both the $\mathrm{CuO}$ and $\mathrm{CuFe}_{2} \mathrm{O}_{4}$ released gaseous $\mathrm{O}_{2}$ but the $\mathrm{CuO}$ released oxygen faster than the $\mathrm{CuFe}_{2} \mathrm{O}_{4}[19]$.

$$
\begin{gathered}
4 \mathrm{CuO}(\mathrm{s}) \leftrightarrow 2 \mathrm{Cu}_{2} \mathrm{O}(\mathrm{s})+\mathrm{O}_{2}(\mathrm{~g}) \\
4 \mathrm{CuFe}_{2} \mathrm{O}_{4}(\mathrm{~s}) \leftrightarrow \mathrm{O}_{2}(\mathrm{~g})+4 \mathrm{CuFeO}_{2}(\mathrm{~s})+2 \mathrm{Fe}_{2} \mathrm{O}_{3}(\mathrm{~s})
\end{gathered}
$$

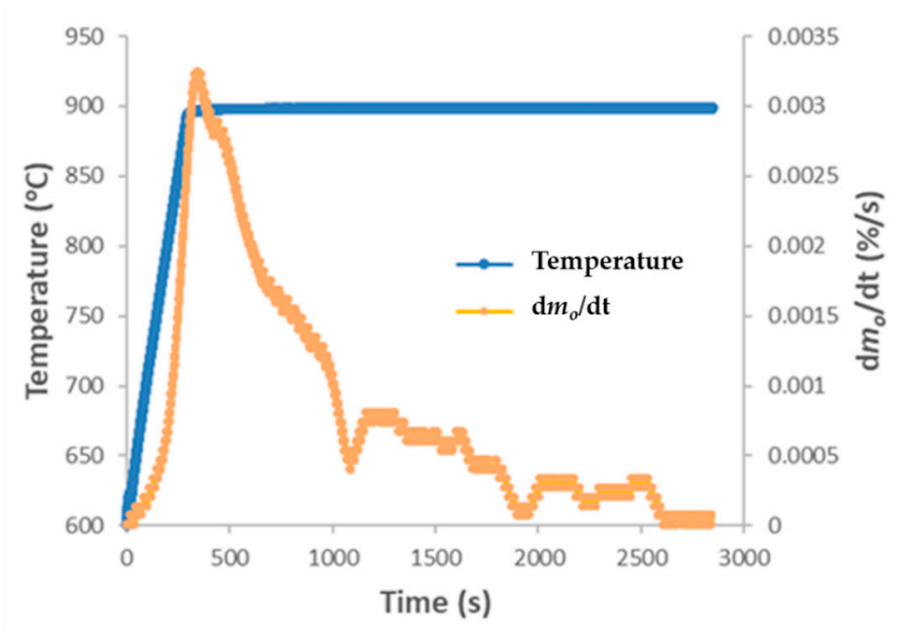

Figure 3. The $\mathrm{Cu}-\mathrm{OC}$ oxygen uncoupling rate $\left(d m_{0} / d t\right)$ and reaction temperature versus time at $900{ }^{\circ} \mathrm{C}$ in $\mathrm{Ar}$ in a TGA-QMS.

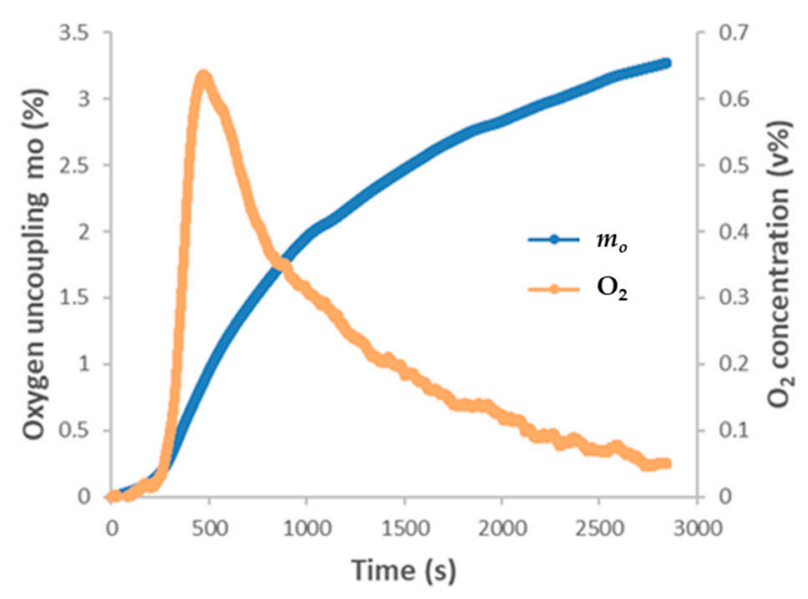

Figure 4. The $\mathrm{Cu}-\mathrm{OC}$ oxygen uncoupling (TGA) and gaseous $\mathrm{O}_{2}$ concentrations (QMS) versus time at $900^{\circ} \mathrm{C}$ in $\mathrm{Ar}$ in a TGA-QMS.

Based on simple stoichiometric calculations, the maximum oxygen uncoupling or oxygen transport capacity of pure $\mathrm{CuO}$ from oxygen uncoupling is $10 \mathrm{wt} . \%$ [2]. The equilibrium oxygen concentration at $900{ }^{\circ} \mathrm{C}$ is about $1.7 \mathrm{vol} . \%$ [3]. Comparing of the oxygen transport capacities of the $\mathrm{Cu}-\mathrm{OC}$ with pure $\mathrm{CuO}$, the $\mathrm{Cu}-\mathrm{OC}$ was estimated to contain approximately $33 \%$ active $\mathrm{CuO}$ (releasing of gaseous $\mathrm{O}_{2}$ ) by 
weight. The active $\mathrm{CuO}$ content in the $\mathrm{Cu}-\mathrm{OC}$ was lower than the ideal $\mathrm{CuO}$ content from the material prepared from chalcopyrite. Based on reaction $\mathrm{R} 1$, the ideal $\mathrm{CuO}$ content should be $\sim 40 \mathrm{wt} . \% \mathrm{CuO}$ since $20 \%$ of the chalcopyrite consists of $\mathrm{SiO}_{2}$. The reason for the lower active $\mathrm{CuO}$ is due to $\mathrm{CuFe}_{2} \mathrm{O}_{4}$ formation from the $\mathrm{CuO}$ and $\mathrm{Fe}_{2} \mathrm{O}_{3}$ reaction. $\mathrm{CuFe}_{2} \mathrm{O}_{4}$ in the tetragonal phase was detected by XRD in the fresh $\mathrm{Cu}-\mathrm{OC}$. $\mathrm{CuFe}_{2} \mathrm{O}_{4}$ in the cubic phase was detected in the $\mathrm{Cu}-\mathrm{OC}$ after the uncoupling based on XRD. Some $\mathrm{CuFe}_{2} \mathrm{O}_{4}$ decomposed and released $\mathrm{O}_{2}$, which also was from the $\mathrm{CuO}$ in $\mathrm{CuFe}_{2} \mathrm{O}_{4}$ (Reaction R4) [26].

Based on the QMS data, the maximum oxygen concentration and the oxygen uncoupling rate $(d X o / d t)$ were 0.68 vol.\% (Figure 4 ) and $0.0012 \mathrm{~s}^{-1}$ at $\mathrm{T}_{\max }$ of $900^{\circ} \mathrm{C}$, respectively (Table 3 ). The pure $\mathrm{CuO}$ oxygen uncoupling rates tested in a fixed bed reactor were $0.0015 \mathrm{~s}^{-1}$ at $\mathrm{T}_{\max }$ of $850^{\circ} \mathrm{C}$ and 0.0077 $\mathrm{s}^{-1}$ at $\mathrm{T}_{\max }$ of $922^{\circ} \mathrm{C}$ for the tests at test temperatures of $850^{\circ} \mathrm{C}$ and $950^{\circ} \mathrm{C}$, respectively (Table 3) [5]. The $\mathrm{Cu}$-OC oxygen uncoupling rate at $950{ }^{\circ} \mathrm{C}$ was close to the value for pure $\mathrm{CuO}$ at $850{ }^{\circ} \mathrm{C}$ and lower than pure $\mathrm{CuO}$ at $950^{\circ} \mathrm{C}$. Both $\mathrm{CuO}$ concentration and temperature affected the oxygen uncoupling rate.

\subsection{Reduction and Reoxidization of $\mathrm{Cu}-\mathrm{OC}$ with Coal Char}

The mixture of $\mathrm{Cu}-\mathrm{OC}$ and char with $\phi=75$ was evaluated through a redox cycle test of reduction in $\mathrm{Ar}$ then reoxidation in air at $900{ }^{\circ} \mathrm{C}$. When the $\mathrm{Cu}-\mathrm{OC}$ and char were heated above $600{ }^{\circ} \mathrm{C}, \mathrm{CO}_{2}$ was generated and detected by the QMS in the product gas and, simultaneously, a sample weight loss was detected by the TGA (Figure 5). Char combustion took place because the $\mathrm{Cu}$-OC began releasing $\mathrm{O}_{2}$ at $\sim 600{ }^{\circ} \mathrm{C}$ from the $\mathrm{Cu}-\mathrm{OC}$ oxygen uncoupling (Figures 3 and 4 ) (Reaction R3 and R4), which combusted the char (Reaction R2). The combustion had a peak at $\sim 838^{\circ} \mathrm{C}$, which was close to the peak temperature $\left(\sim 833^{\circ} \mathrm{C}\right)$ for the reaction of pure $\mathrm{CuO}$ and coal in a TGA under $\mathrm{N}_{2}$ [27]. The maximum combustion rate was $0.028 \% / \mathrm{s}$ (Figure 6 ) and was eight times faster than the $\mathrm{Cu}-\mathrm{OC}$ oxygen uncoupling rate (without char) because the combustion reaction (Reaction R2) consumed the oxygen from the $\mathrm{Cu}$-OC uncoupling (Reaction R3 and R4) and increased the Cu-OC oxygen uncoupling rate. The final reduction $m_{\text {red }}$ was $4.3 \%$ which was the same as the theoretical $m_{\text {red }} 4.3 \%$ based on the char being fully combusted to $\mathrm{CO}_{2}$ (Reaction R2) and gaseous oxygen being released from the $\mathrm{Cu}-\mathrm{OC}$. This means that the char was converted to $\mathrm{CO}_{2}$ in the reduction of $\mathrm{Cu}-\mathrm{OC}$ with the char. The product gas was mainly $\mathrm{CO}_{2}$ with a trace amount of $\mathrm{O}_{2}$ detected by the QMS (Figure 5). The $\mathrm{CO}_{2}$ conversion efficiency $\mathrm{Sco}_{2}$ was 1 . The final carbon conversion efficiency $X_{c}$ was 0.94 (theoretical $X_{c}=1$ ) and the maximum rate $d X c / d t$ was $0.005 \mathrm{~s}^{-1}$ based on the QMS data (Table 3).

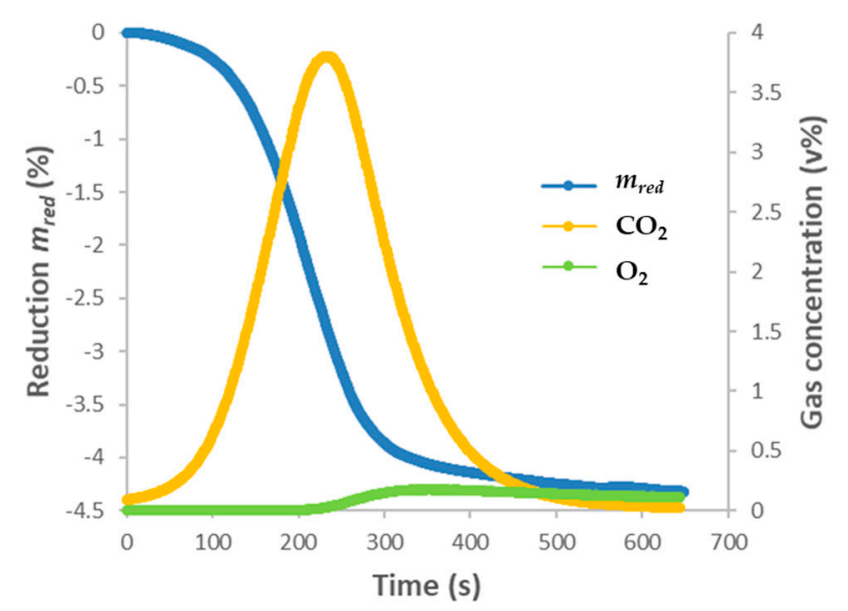

Figure 5. The reduction $m_{\text {red }}$ of $\mathrm{Cu}-\mathrm{OC}$ with coal char, $\mathrm{CO}_{2}$ and $\mathrm{O}_{2}$ concentrations (QMS) versus time in $\mathrm{Ar}$ at $900^{\circ} \mathrm{C}$ in a TGA-QMS.

The reduced $\mathrm{Cu}-\mathrm{OC}$ was fully oxidized at $900^{\circ} \mathrm{C}$ in air. The final oxidation $m_{0 x}$ was $3.2 \%$ lower than the final $m_{\text {red }}$ because of the $m_{o x}$ and $m_{\text {red }}$ calculations (Equations (1) and (2)). In the $m_{\text {red }}$ calculation, $m$ included both char and the Cu-OC. But for $m_{o x}$, only $\mathrm{Cu}-\mathrm{OC}$ was counted in the reoxidation 
calculation. The final $m_{0 x}$ was close to the theoretical $m_{0 x} 3.0 \%$ based on the oxygen used to combust the char (Reaction R3) and the $m_{o x}$ calculation (Equation (2)) including char in the sample weight. The slightly higher $m_{0 x}$ was due to extra $\mathrm{O}_{2}$ released during the reduction and this was also reoxidized. This additional oxidation was not included in the theoretical $m_{o x}$. The maximum oxidation rate was $0.012 \% / \mathrm{s}$, less than half the reduction rate of the OC with char $(0.028 \% / \mathrm{s})$ (Figure 6$)$. The temperatures during the reoxidation were slightly higher than during the reduction due to exothermal reoxidation (Reaction R3) (Figure 6).

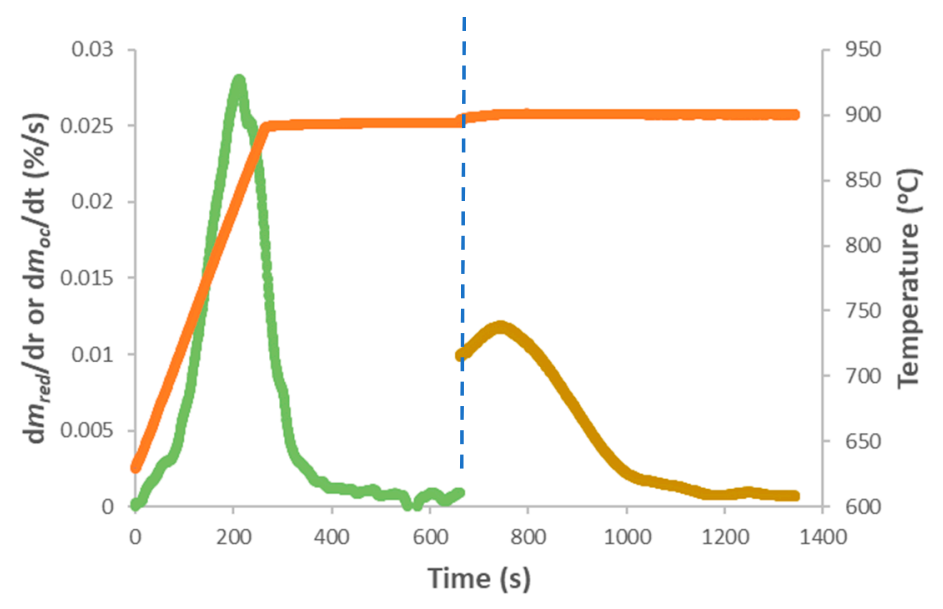

Figure 6. The reduction rate of $\mathrm{Cu}-\mathrm{OC}$ with coal char in $\mathrm{Ar}\left(d m_{\text {red }} / d t\right)$, reoxidation rate of reduced $\mathrm{Cu}-\mathrm{OC}$ in air $\left(d m_{o c} / d t\right)$, and the reaction temperatures versus time at $900{ }^{\circ} \mathrm{C}$ in a TGA-QMS.

The $\mathrm{Cu}-\mathrm{OC}$ reduced with the char primarily consisted of $\mathrm{Cu}_{2} \mathrm{O}$ and $\mathrm{CuFeO}_{2}$ which were reoxidized to $\mathrm{CuO}$ and $\mathrm{CuFe}_{2} \mathrm{O}_{4}$ (tetragonal and cubic phases) based on XRD analysis (Table 2). The experimental results were very close to the theoretical calculations based on active $\mathrm{CuO}$ uncoupling. For the $\mathrm{Cu}-\mathrm{OC}$, $\phi=75$ was used to fully combust the char to $\mathrm{CO}_{2}$. For pure $\mathrm{CuO} \phi=26$ was selected [5]. Based on a comparison of the $\phi$ of the $\mathrm{Cu}-\mathrm{OC}$ with that of pure $\mathrm{CuO}$, the $\mathrm{Cu}-\mathrm{OC}$ was estimated to contain $\sim 35 \%$ of active $\mathrm{CuO}$ by weight.

\subsection{Recyclability of Cu-OC in Coal Char CLOU Tested in a TGA-QMS and Fixed-Bed Reactor-QMS}

Figure 7 shows the reactivities of five cycles of a mixture of $\mathrm{Cu}-\mathrm{OC}$ and coal char in $\mathrm{Ar}$ at $900{ }^{\circ} \mathrm{C}$ then oxidized in air at $900^{\circ} \mathrm{C}$. Fresh coal char was added to the oxidized OC, which also contained any residual coal ash, after each cycle. The reactivities and the rates for the reduction of $\mathrm{Cu}-\mathrm{OC}$ with char were similar for all five cycles. For the reoxidation of the $\mathrm{Cu}-\mathrm{OC}$ with char, the oxidation $m_{0 x}$ and the rates for cycles 2, 4, and 5 were similar but were slight lower for cycle 1 and 3 (Figure 7). This is due to slightly lower oxygen concentrations in the oxidation gas $\left(\mathrm{O}_{2} / \mathrm{Ar}\right)$ at beginning of the oxidation. Overall, the result indicates that the $\mathrm{Cu}-\mathrm{OC}$ was stable during the five cycle tests. 


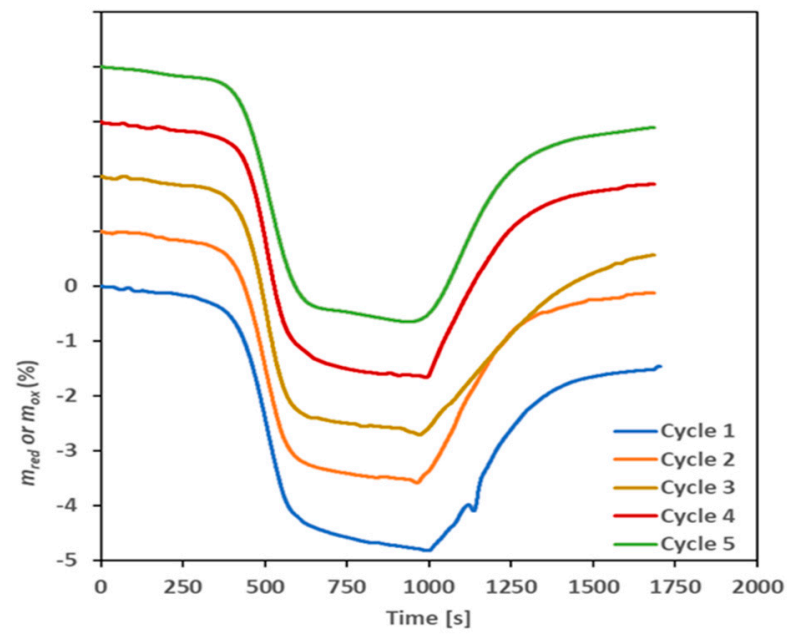

Figure 7. The reactivities of the $\mathrm{Cu}-\mathrm{OC}$ with coal char $m_{r e d}$ in $\mathrm{Ar}$ and $m_{o c}$ in air of five cycles versus time at $900{ }^{\circ} \mathrm{C}$ in a TGA-QMS.

The recyclability of the $\mathrm{Cu}-\mathrm{OC}$ in coal char CLOU also was tested for five cycles in the fixed bed reactor using the same procedure that was used for the TGA tests. Figure 8 shows the carbon conversion efficiency $\mathrm{Xc}$ and generated $\mathrm{CO}_{2}$ concentration for the reduction of $\mathrm{Cu}-\mathrm{OC}$ with coal char in one cycle of the five-cycle test. The $\mathrm{CO}_{2}$ conversion efficiency $\mathrm{Sco}_{2}$ was 1 because the generated gas was mainly $\mathrm{CO}_{2}$ with little $\mathrm{O}_{2}$ and $\mathrm{H}_{2} \mathrm{O}$. There were two $\mathrm{CO}_{2}$ peaks, a very small peak around $600{ }^{\circ} \mathrm{C}$ and a large sharp peak around $835^{\circ} \mathrm{C}$. This was similar to the reduction test using pure $\mathrm{CuO}$ with PRB coal char at $950{ }^{\circ} \mathrm{C}$, which had a small peak at $\sim 670{ }^{\circ} \mathrm{C}$ and a large peak at $833^{\circ} \mathrm{C}$ [5]. The small peak may be due to the small particle size fraction of the $\mathrm{CuO}$ that released oxygen at a lower temperature because a small peak at a lower temperature of $675^{\circ} \mathrm{C}$ along with a large sharp were also observed in pure $\mathrm{CuO}$ oxygen uncoupling test in Ar. The carbon conversion efficiency $\mathrm{Xc}$ was 0.95 , close to the theoretical $X c=1$, which means that the carbon in the coal char was close to complete conversion (Table 3). The carbon conversion rate $d X c / d t$ was $0.006 \mathrm{~s}^{-1}$ (Table 3). The reaction rates of pure $\mathrm{CuO}$ with PRB coal char were $0.006 \mathrm{~s}^{-1}$ and $0.011 \mathrm{~s}^{-1}$ at test temperatures of $850{ }^{\circ} \mathrm{C}$ and $950{ }^{\circ} \mathrm{C}$ using the same fixed bed reactor-QMS (Table 3) [5]. For $40 \mathrm{wt} . \% \mathrm{CuO}$ with $\mathrm{Fe}_{2} \mathrm{O}_{3}$ and $\mathrm{SiO}_{2} \mathrm{OC}$ synthesized by mechanical mixing followed by pelletizing by pressure at $\phi=67$, the carbon conversion efficiency rate at $1000{ }^{\circ} \mathrm{C}$ was $0.0077 \mathrm{~s}^{-1}$ [28] and close to the rate of the $\mathrm{Cu}$-OC from the $\mathrm{Cu}$-ore in this study

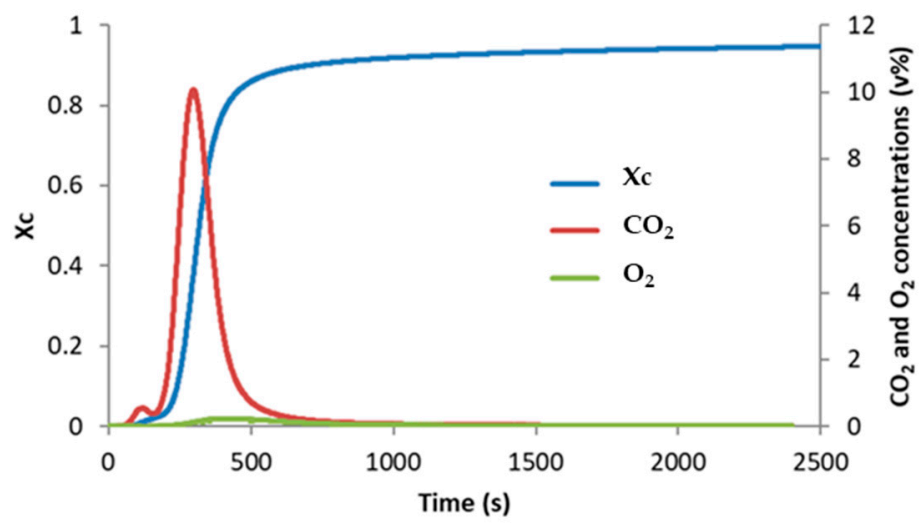

Figure 8. The carbon conversion efficiency $\mathrm{Xc}_{c}$ and generated $\mathrm{CO}_{2}$ concentration $(\mathrm{v} \%)$ in the reduction of $\mathrm{Cu}-\mathrm{OC}$ with coal char versus time in one cycle of the five-cycle test in a fixed bed reactor-QMS.

For the five-cycle test, the carbon conversion efficiency and carbon conversion rates were similar for all five cycles. The results from the fixed bed reactor were similar to the TGA results since both are the same type of reactor the carbon conversion $X c$ and rate $d X c / d t$ measured in TGA-QMS were 
slight lower than in the fixed-bed reactor (Table 3) because sample in the fixed-bed reactor was heated faster than in the TGA. In the fixed-bed reactor, The fixed-bed reactor was preheated to $400{ }^{\circ} \mathrm{C}$ and had heating rate $\sim 65^{\circ} \mathrm{C} / \mathrm{min}[5]$.

The BET surface areas of the fresh $\mathrm{Cu}-\mathrm{OC}$ and the used $\mathrm{Cu}-\mathrm{OC}$ after five cycles in the fixed bed reactor were 0.36 and $0.2 \mathrm{~m}^{2} / \mathrm{g}$, respectively. Both the fresh and used $\mathrm{Cu}-\mathrm{OC}$ had low surface areas. The fresh Cu-OC surface area in this study was close to the reported by Zhao et al. for a fresh OC prepared from natural copper ore $(21 \mathrm{wt} . \% \mathrm{CuO})$ for CLOU, $0.217 \mathrm{~m}^{2} / \mathrm{g}$ [19]. Their used OC, after $10 \mathrm{~h}$ reduction/oxidation CLOU cycles with anthracite coal in a batch fluidized bed reactor, had a BET surface area of $0.115 \mathrm{~m}^{2} / \mathrm{g}$. They explained the slight decrease in BET surface area of the used $\mathrm{OC}$ as being due to slight sintering of the $\mathrm{OC}$ particles or blockage of the pores and available surface area by the ash generated from coal CLOU, but the impact was very limited [19]. In this study, there was no significant agglomeration observed at $900{ }^{\circ} \mathrm{C}$. After a redox cycle, the OC particles were very weakly bound together but easily loosened to powder again by light pressure. Tian et al. studied $\mathrm{Cu}$ ore OC with lignite coal in a batch-scale fluidized bed reactor at $950{ }^{\circ} \mathrm{C}$ for $10 \mathrm{cycles}$ and observed a sintering problem in the later cycles [20]. In the future, higher temperatures will be tested to evaluate the sintering, agglomeration, or partial melting of the particles.

Natural ore has potential as a competitive oxygen carrier in solid fuel CLOU based on its reactivity as observed in this study. Based on extensive research on Fe-based OC for iG-CLC, the reactivity of mineral OC is typically lower than synthetic OC [4]. Research on the mineral Fe-OC is continuing because the mineral OC is inexpensive compared to the synthetic OC. For CLOU, a low-cost OC is even more important than iG-CLC because CLOU requires more OC to fully covert the fuels to $\mathrm{CO}_{2}$ due to its low oxygen capacity. Moreover, low cost is preferred for solid fuel CLOU due to ash from fuel combustion that causes loss of OC reactivity and loss of OC with separation of the ash. Mineral Cu-based OC is much lower in cost than synthetic $\mathrm{Cu}$-OC based on $\mathrm{Cu}$ material prices. $\mathrm{Cu}$ ore (copper concentrate with $20-30 \% \mathrm{Cu}$ ) costs approximately $\$ 0.0695 / \mathrm{lb}$ [29], much cheaper than $\mathrm{Cu}$ metal at about $\$ 2.8875 / \mathrm{lb}$ [30]. Cu powder is used to produce $\mathrm{CuO}$ by roasting it in air among other different $\mathrm{CuO}$ processes. Moreover, $\mathrm{Cu}$-ores are abundant. Converting $\mathrm{Cu}$-ore to an $\mathrm{OC}$ is a simple process as compared to production of a synthetic $\mathrm{Cu}-\mathrm{Fe} \mathrm{OC}$ which can require multiple steps and use many chemicals. Future investigation to increase the $\mathrm{CuO}$ content of mineral $\mathrm{Cu}$-based $\mathrm{OC}$ and operating at higher temperatures could increase the reactivity and make it a more attractive OC. For commercial applications, further study of the long-term cyclic stability of the Cu-OCs with coal is required. Increasing the $\mathrm{CuO}$ content in the $\mathrm{Cu}-\mathrm{OC}$ derived from natural copper ore is needed to increase oxygen transfer capacity and lower the ratio of $\mathrm{Cu}-\mathrm{OC}$ to fuel to lower the operational cost of a future plant.

\section{Conclusions}

This study investigated Cu-based OCs derived from natural minerals for solid fuel CLOU to potentially lower the OC cost. Chalcopyrite, which contains primarily $\mathrm{CuFeS}_{2}$, has potential as a $\mathrm{Cu}-\mathrm{OC}$ resource. It is one of the primary ores of copper, so is readily available. The $\mathrm{Cu}-\mathrm{OC}$ used in this study was prepared by simply heating ground chalcopyrite in air $900{ }^{\circ} \mathrm{C}$ to remove the sulfur. The prepared $\mathrm{Cu}-\mathrm{OC}$ consisted primarily of $\mathrm{CuO}$ and $\mathrm{CuFe}_{2} \mathrm{O}_{4}\left(\mathrm{CuOFe}_{2} \mathrm{O}_{3}\right)$ from the XRD analysis and had oxygen uncoupling properties based on TGA-QMS testing. The oxygen transport capacity of $\mathrm{Cu}-\mathrm{OC}$ was $3.3 \%$ from both $\mathrm{CuO}$ and $\mathrm{CuFe}_{2} \mathrm{O}_{4}$ oxygen uncoupling. For the reduction of the $\mathrm{Cu}-\mathrm{OC}$ with coal during $\mathrm{CLOU}$ at $900^{\circ} \mathrm{C}$ in $\mathrm{Ar}$, the coal char conversion efficiency Xc was 0.95 and the product gas was primarily $\mathrm{CO}_{2}$ with trace $\mathrm{O}_{2}$. The $\mathrm{Cu}-\mathrm{OC}$ showed high reactivity and cyclic stability in a five-cycle test. Therefore, the natural ore has potential as a competitive oxygen carrier in solid fuel CLOU based on its reactivity in this study. For commercial applications, further study of the long-term cyclic stability of the $\mathrm{Cu}-\mathrm{OC}$ with coal is certainly required. Increasing the $\mathrm{CuO}$ content in the $\mathrm{Cu}-\mathrm{OC}$ made from natural copper ore and increasing the reaction temperature are needed to improve the 
oxygen transfer capacity and lower the ratio of $\mathrm{Cu}-\mathrm{OC}$ to fuel to reduce the operational cost of a CLOU system.

Author Contributions: P.W. is the primary author of this article; B.H., N.M., D.S. and D.B. participated in materials preparation and characterizations, test system setup, discussions, and to the writing and editing of the manuscript.

Funding: This research was supported by the Department of Energy, National Energy Technology Laboratory.

Acknowledgments: Special thanks to Sittichar Natesakhawat for conducting sample BET surface analysis. Disclaimer: This report was prepared as an account of work sponsored by the Department of Energy, National Energy Technology Laboratory, an agency of the United States Government. Neither the United States Government nor any agency thereof, nor any of their employees, makes any warranty, express or implied, or assumes any legal liability or responsibility for the accuracy, completeness, or usefulness of any information, apparatus, product, or process disclosed, or represents that its use would not infringe privately owned rights. Reference herein to any specific commercial product, process, or service by trade name, trademark, manufacturer, or otherwise does not necessarily constitute or imply its endorsement, recommendation, or favoring by the United States Government or any agency thereof. The views and opinions of authors expressed herein do not necessarily state or reflect those of the United States Government or any agency thereof.

Conflicts of Interest: The authors declare no conflict of interest.

\section{References}

1. Adanez, J.; Abad, A.; Mendiara, T.; Gayan, P.; de Diego, L.F.; Garcia-Labiano, F. Chemical looping combustion of solid fuels. Prog. Energy Combust. Sci. 2018, 65, 6-66. [CrossRef]

2. Wang, P.; Means, N.; Shekhawat, D.; Berry, D.; Massoudi, M. Chemical-looping combustion and gasification of coals and oxygen carrier development: A brief review. Energies 2015, 8, 10605-10635. [CrossRef]

3. Mattisson, T.; Lyngfelt, A.; Leion, H. Chemical-looping with oxygen uncoupling for combustion of solid fuels. Int. J. Greenh. Gas Control 2009, 3, 11-19. [CrossRef]

4. Adanez, J.; Abad, A.; Garcia-Labiano, F.; Gayan, P.; de Diego, L.F. Progress in chemical-looping combustion and reforming technologies. Prog. Energy Combust. Sci. 2012, 38, 215-282. [CrossRef]

5. Wang, P.; Means, N.; Howard, B.H.; Shekhawat, D.; Berry, D. The reactivity of cuo oxygen carrier and coal in chemical-looping with oxygen uncoupled (clou) and in-situ gasification chemical-looping combustion (ig-clc). Fuel 2018, 217, 642-649. [CrossRef]

6. Adanez-Rubio, I.; Abad, A.; Gayan, P.; de Diego, L.F.; Garcia-Labiano, F.; Adanez, J. Performance of clou process in the combustion of different types of coal with co2 capture. Int. J. Greenh. Gas Control 2013, 12, 430-440. [CrossRef]

7. Abad, A.; Adanez-Rubio, I.; Gayan, P.; Garcia-Labiano, F.; de Diego, L.F.; Adanez, J. Demonstration of chemical-looping with oxygen uncoupling (clou) process in a $1.5 \mathrm{kw}(\mathrm{th})$ continuously operating unit using a cu-based oxygen-carrier. Int. J. Greenh. Gas Control 2012, 6, 189-200. [CrossRef]

8. Adanez-Rubio, I.; Abad, A.; Gayan, P.; de Diego, L.F.; Garcia-Labiano, F.; Adanez, J. Biomass combustion with co2 capture by chemical looping with oxygen uncoupling (clou). Fuel Process. Technol. 2014, 124, 104-114. [CrossRef]

9. Adanez-Rubio, I.; Arjmand, M.; Leion, H.; Gayan, P.; Abad, A.; Mattisson, T.; Lyngfelt, A. Investigation of combined supports for cu-based oxygen carriers for chemical-looping with oxygen uncoupling (clou). Energy Fuels 2013, 27, 3918-3927. [CrossRef]

10. Azimi, G.; Leion, H.; Mattisson, T.; Ryden, M.; Snijkers, F.; Lyngfelt, A. Mn-fe oxides with support of mgal2o4, ceo2, zro2 and y2o3-zro2 for chemical-looping combustion and chemical-looping with oxygen uncoupling. Ind. Eng. Chem. Res. 2014, 53, 10358-10365. [CrossRef]

11. Pour, N.M.; Leion, H.; Ryden, M.; Mattisson, T. Combined cu/mn oxides as an oxygen carrier in chemical looping with oxygen uncoupling (clou). Energy Fuels 2013, 27, 6031-6039. [CrossRef]

12. Adanez-Rubio, I.; Gayan, P.; Abad, A.; Garcia-Labiano, F.; de Diego, L.F.; Adanez, J. Kinetic analysis of a cu-based oxygen carrier: Relevance of temperature and oxygen partial pressure on reduction and oxidation reactions rates in chemical looping with oxygen uncoupling (clou). Chem. Eng. J. 2014, 256, 69-84. [CrossRef]

13. Clayton, C.K.; Whitty, K.J. Measurement and modeling of decomposition kinetics for copper oxide-based chemical looping with oxygen uncoupling. Appl. Energy 2014, 116, 416-423. [CrossRef] 
14. Peterson, S.B.; Konya, G.; Clayton, C.K.; Lewis, R.J.; Wilde, B.R.; Eyring, E.M.; Whitty, K.J. Characteristics and clou performance of a novel sio2-supported oxygen carrier prepared from cuo and beta-sic. Energy Fuels 2013, 27, 6040-6047. [CrossRef]

15. Hu, W.T.; Donat, F.; Scott, S.A.; Dennis, J.S. Kinetics of oxygen uncoupling of a copper based oxygen carrier. Appl. Energy 2016, 161, 92-100. [CrossRef]

16. Matzen, M.; Pinkerton, J.; Wang, X.M.; Demirel, Y. Use of natural ores as oxygen carriers in chemical looping combustion: A review. Int. J. Greenh. Gas Control 2017, 65, 1-14. [CrossRef]

17. Wang, K.; Tian, X.; Zhao, H.B. Sulfur behavior in chemical-looping combustion using a copper ore oxygen carrier. Appl. Energy 2016, 166, 84-95. [CrossRef]

18. Wang, K.; Zhao, H.B.; Tian, X.; Fang, Y.F.; Ma, J.C.; Zheng, C.G. Chemical-looping with oxygen uncoupling of different coals using copper ore as an oxygen carrier. Energy Fuels 2015, 29, 6625-6635. [CrossRef]

19. Zhao, H.B.; Wang, K.; Fang, Y.F.; Ma, J.C.; Mei, D.F.; Zheng, C.G. Characterization of natural copper ore as oxygen carrier in chemical-looping with oxygen uncoupling of anthracite. Int. J. Greenh. Gas Control 2014, 22, 154-164. [CrossRef]

20. Tian, X.; Zhao, H.B.; Wang, K.; Ma, J.C.; Zheng, C.G. Performance of cement decorated copper ore as oxygen carrier in chemical-looping with oxygen uncoupling. Int. J. Greenh. Gas Control 2015, 41, 210-218. [CrossRef]

21. Wen, Y.-Y.; Li, Z.-S.; Xu, L.; Cai, N.-S. Experimental study of natural cu ore particles as oxygen carriers in chemical looping with oxygen uncoupling (clou). Energy Fuels 2012, 26, 3919-3927. [CrossRef]

22. Calcutt, V. Introduction to Copper: Mining \& Extraction. Copper Development Association Inc., 2001. Available online: https:/www.copper.org/publications/newsletters/innovations/2001/08/intro_mae.html (accessed on 12 October 2018).

23. Baba, A.A.; Ayinla, K.I.; Adekola, F.A.; Ghosh, M.K.; Ayanda, O.S.; Bale, R.B.; Sheik, A.R.; Pradhan, S.R. A review on novel techniques for chalcopyrite ore processing. Int. J. Min. Eng. Miner. Process. 2012, 1, 1-16. [CrossRef]

24. Teck-Metals-Ltd. Andacollo Copper Concentrate Safety Data Sheet. 2015. Available online: https://www.teck.com/media/Andacollo-Copper-Concentrate-SDS.pdf (accessed on 10 September 2018).

25. Gayan, P.; Adanez-Rubio, I.; Abad, A.; de Diego, L.F.; Garcia-Labiano, F.; Adanez, J. Development of cu-based oxygen carriers for chemical-looping with oxygen uncoupling (clou) process. Fuel 2012, 96, 226-238. [CrossRef]

26. Wang, B.; Yan, R.; Zhao, H.; Zheng, Y.; Liu, Z.; Zheng, C. Investigation of chemical looping combustion of coal with cufe2o4 oxygen carrier. Energy Fuels 2011, 25, 3344-3354. [CrossRef]

27. Cao, Y.; Pan, W.-P. Investigation of chemical looping combustion by solid fuels. 1. Process analysis. Energy Fuels 2006, 20, 1836-1844. [CrossRef]

28. Wang, P.; Howard, B.H.; Means, N.; Shekhawat, D. Bimetallic cu-fe Oxygen Carriers for Coal Chemical-Looping Combustion. In Proceedings of the 255th American Chemical Society National Meeting \& Exposition, New Orleans, LA, USA, 18-22 March 2018.

29. Fastmarkets-MB. Copper Concentrate tc/rcs Decline Further as Traders Bid Aggressively for Tonnes. 2018. Available online: https://www.metalbulletin.com/Article/3787933/Copper-concentrate-TCRCs-declinefurther-as-traders-bid-aggressively-for-tonnes.html (accessed on 9 March 2019).

30. Fastmarkets-MB. LIVE Futures Report 08/03: Comex Copper Price Suffers Further Losses in Final Session. 2018. Available online: https://www.metalbulletin.com/Article/3863299/LIVE-FUTURES-REPORT-0803Comex-copper-price-suffers-further-losses-in-final-session.html (accessed on 10 March 2019).

(C) 2019 by the authors. Licensee MDPI, Basel, Switzerland. This article is an open access article distributed under the terms and conditions of the Creative Commons Attribution (CC BY) license (http://creativecommons.org/licenses/by/4.0/). 